\title{
Evaluation of the anti-inflammatory and analgesic effects of green tea (Camellia sinensis) in mice ${ }^{1}$
}

\author{
Matheus Alves de Lima Mota', José Saul Peixoto Landim', Thiago Sousa Silva TarginoI, Silvia Fernandes Ribeiro da Silva ${ }^{I I}$, \\ Sônia Leite da Silva ${ }^{I I}$, Márcio Roberto Pinho Pereira ${ }^{\text {III }}$ \\ DOI: http://dx.doi.org/10.1590/S0102-865020150040000002 \\ ${ }^{\mathrm{I}}$ Graduate student, School of Medicine, University of Fortaleza (UNIFOR), Fortaleza-CE, Brazil. Technical procedures. \\ IIPhD, Associate Professor, Health Sciences Center, UNIFOR, Fortaleza-CE, Brazil. Interpretation of data, critical revision, supervised all phases of \\ the study. \\ IIIPhD, Associate Professor, Health Sciences Center, UNIFOR, Fortaleza-CE, Brazil. Responsible for conception, design, intellectual and scientific \\ content of the study.
}

\section{ABSTRACT \\ PURPOSE: To evaluate the anti-inflammatory and analgesic effects of green tea (Camellia sinensis) in mice.}

METHODS: The anti-inflammatory effect of alcoholic extracts of green tea (AE) was evaluated in a cell migration assay with four groups of six Swiss mice receiving $0.07 \mathrm{~g} / \mathrm{Kg}$ or $0.14 \mathrm{~g} / \mathrm{Kg}$ EA (treatment groups), saline (negative control) or $10 \mathrm{mg} / \mathrm{Kg}$ indomethacin (positive control) by gavage. One hour later $300 \mu \mathrm{g}$ carrageen an was administered intraperitoneally or subcutaneously. The analgesic effect was evaluated using four groups of six animals receiving $0.07 \mathrm{~g} / \mathrm{Kg}$ or $0.14 \mathrm{~g} / \mathrm{Kg}$ EA, saline or $10 \mathrm{mg} / \mathrm{Kg}$ indomethacin subcutaneously, followed 30 minutes later by $1 \%$ acetic acid.

RESULTS: When administered subcutaneously at either dose $(0.07 \mathrm{~g} / \mathrm{Kg}$ and $0.14 \mathrm{~g} / \mathrm{Kg}), \mathrm{AE}$ inhibited carrageenan-induced cell migration $(p<0.05)$. However, when administered by gavage, only the latter $(0.14 \mathrm{~g} / \mathrm{Kg})$ was efficient $(p<0.05)$. AE at both doses $(0.07 \mathrm{~g} /$ $\mathrm{Kg}$ and $0.14 \mathrm{~g} / \mathrm{Kg}$ ) inhibited abdominal contortions $(p<0.05)$, but the effect was not dose-dependent.

CONCLUSION: Green tea was shown to have analgesic and anti-inflammatory properties and may constitute a natural treatment option in chronic inflammatory disorders.

Key words: Camellia sinensis. Catechin. Anti-inflammatory Agents. Analgesics. Mice. 


\section{Introduction}

After water, tea is one of the most popular beverages in the world ${ }^{1}$. A significant part of this tea is prepared with leaves of the shrub Camellia sinensis in the form of green tea, oolong or black tea, especially appreciated in China and Japan. Studies conducted in these countries show that green tea contains a wide array of organic compounds, such as polyphenols and catechin (which can potentially reduce the risk of cardiovascular and neurodegenerative disorders), in addition to substances with hypoglycemiant and anticancer properties ${ }^{2-5}$.

Green tea is made with fresh leaves which are boiled to avoid fermentation, resulting in a dry and stable product ${ }^{6}$. Catechin, represented by epicatechin, epicatechin 3-gallate (ECG), 3-epigallocatechin and epigallocatechin 3-gallate (EGCG), are the most important flavonoids in tea. These colorless, watersoluble compounds contribute to the characteristic bitterness and adstringence of tea ${ }^{8,9}$.

Among other benefits, green tea is generally held to be anti-inflammatory ${ }^{10}$. Inflammation is induced by endogenous or exogenous stimulation of the vascularized connective tissue which in turn produces and releases chemical mediators with the purpose of reparing tissue injury ${ }^{11}$. In chronic inflammation, thrombi may be formed due to lipid peroxidation causing vascular occlusion, or neoplasms may develop ${ }^{12,13}$.

Diets rich in antioxidant compounds have been proposed to minimize inflammatory stimuli, atheromatous plaque formation and risk of malignancy ${ }^{14}$. According to Ryu and Chung ${ }^{15}$, green tea displays antioxidant (free radical scavengers) and metalchelating activity in addition to inhibiting lipoperoxidation due to the presence of polyphenols (especially catechin), alkaloids, vitamins and mineral salts with antioxidant, chemoprotective, anti-inflammatory and anticarcinogenic properties ${ }^{14-16}$.

In view of the wide range of pharmacological properties of catechin, the purpose of the present study was to evaluate the anti-inflammatory and analgesic effects of green tea (Camellia sinensis) in mice.

\section{Methods}

The study was previously approved by the Institutional Animal Care and Use Committee of the University of Fortaleza (\#008/2009).

Forty-eight male Swiss mice weighing 25-35 grams were used in the study. The animals were supplied by the experimental animal facility of the Health Sciences Center at the University of Fortaleza, distributed in groups of six animals each and accommodated in cages $(30 \times 17 \times 15 \mathrm{~cm})$ in a controlled environment (circadian cycle, $25^{\circ} \mathrm{C}$, water and Fri-Ribe ${ }^{\circledR}$ rat chow ad libitum throughout the experiment).

\section{Preparation of alcoholic extract of leaves of Camel- lia sinensis}

Leaves $(95 \mathrm{~g})$ of $C$. sinensis (Amor à Vida Produtos Naturais $^{\circledR}$ ) were ground and macerated with $400 \mathrm{~mL}$ absolute ethanol at room temperature for five days. The extract was then filtered and the maceration process was repeated with the residue. The solvent of the extract was evaporated by heating in a water bath at $60^{\circ} \mathrm{C}$ until obtaining a final volume of $25 \mathrm{~mL}$. During the entire procedure, the extract was shielded from direct light exposure. Finally, $70 \mathrm{~mL}$ distilled water was added to the extract to make $95 \mathrm{~mL}$ solution with a drug concentration of $1 \mathrm{~g} / \mathrm{mL}$. The fraction was stored in an amber vial at $4^{\circ} \mathrm{C}$ until the time of use.

The highest dose of extract administered in the study $(0.14$ $\mathrm{g} / \mathrm{kg}$ ) was based on the consumption of 1 liter green tea (prepared with $10 \mathrm{~g}$ C. sinensis leaves) by an individual weighing $70 \mathrm{Kg}$.

\section{Evaluation of inhibition of inflammation}

Cell migration to the peritoneal cavity was evaluated as described by Spiller et al. ${ }^{17}$. Inflammation was induced in all animals by intraperitoneal injection of $300 \mu \mathrm{L}$ solution containing $300 \mathrm{mg}$ carrageenan diluted in $0.9 \% \mathrm{NaCl}$ at $1: 1$.

\section{Method 1: oral application of green tea extract:}

Treatment group $1(\mathrm{n}=12)$ : Two groups of six animals each received, respectively, $0.07 \mathrm{~g} / \mathrm{Kg}$ and $0.14 \mathrm{~g} / \mathrm{Kg}$ green tea extract by gavage one hour before carrageenan administration.

Negative control group $(n=6)$ : The animals received saline solution by gavage one hour before carrageenan administration.

Positive control group $(n=6)$ : The animals received indomethacin solution $(10 \mathrm{mg} / \mathrm{kg})$ by gavage one hour before carrageenan administration.

Method 2: subcutaneous application of green tea extract:

Treatment group $1(\mathrm{n}=12)$ : Two groups of six animals each received, respectively, $0.07 \mathrm{~g} / \mathrm{Kg}$ and $0.14 \mathrm{~g} / \mathrm{Kg}$ green tea extract subcutaneously one hour before carrageenan administration.

Negative control group $(n=6)$ : The animals received saline solution subcutaneously one hour before carrageenan administration. 
Positive control group $(n=6)$ : The animals received indomethacin solution $(10 \mathrm{mg} / \mathrm{kg})$ subcutaneously one hour before carrageenan administration.

Four hours after carrageenan administration, the animals were euthanized by cervical dislocation, $10 \mathrm{~mL}$ saline solution containing $0.1 \%$ heparin was injected intraperitoneally and the abdomen was shaken lightly to homogenize the migratory cells. Then, by way of laparotomy, $5 \mathrm{~mL}$ peritoneal fluid was retrieved with a plastic Pasteur pipette for migratory cell count.

\section{Total cell count}

Aliquots of $20 \mu \mathrm{L}$ samples were added to $380 \mu \mathrm{L}$ Turk solution. Subsequently, $20 \mu \mathrm{L}$ of the resulting solution was placed in a Newbauer chamber for total cell count under light microscopy.

\section{Evaluation of analgesic effect}

To evaluate the analgesic effect, $1 \%$ acetic acid $(0.1 \mathrm{~mL} / 10 \mathrm{~g})$ diluted to $1 \%$ in distilled water was injected in four groups of six animals each. Abdominal contortions were counted during $20 \mathrm{~min}$, beginning $10 \mathrm{~min}$ after acetic acid administration.

Treatment group $(n=12)$ : Two groups of six animals each received, respectively, $0.07 \mathrm{~g} / \mathrm{Kg}$ and $0.14 \mathrm{~g} / \mathrm{Kg}$ green tea extract subcutaneously $30 \mathrm{~min}$ before acetic acid administration.

Negative control group $(n=6)$ : The animals received $0.9 \%$ saline solution subcutaneously $30 \mathrm{~min}$ before acetic acid administration.

Positive control group $(n=6)$ : The animals received indomethacin solution $(10 \mathrm{mg} / \mathrm{kg})$ diluted in $5 \%$ sodium bicarbonate (1:1) subcutaneously $30 \mathrm{~min}$ before acetic acid administration.

\section{Statistical analysis}

The data were submitted to variance analysis followed by the Student-Newman-Keuls test, using the software GraphPad Prism. Mean values \pm standard deviation for each group were compared. The level of statistical significance was set at $5 \%$ $(p<0.05)$.

\section{Results}

Figures 1 and 2 show the results of the inhibition of inflammation following the administration, by gavage or subcutaneous injection, respectively, of $0.07 \mathrm{~g} / \mathrm{Kg}$ and $0.14 \mathrm{~g} / \mathrm{Kg}$ alcoholic green tea extract to Swiss mice one hour prior to administration of carrageenan.
When the extract was administered by gavage, cell migration was only inhibited at $0.14 / \mathrm{Kg}(p<0.05)$, but when the extract was injected subcutaneously, inhibition was observed at both dosage levels $(0.07 \mathrm{~g} /$ $\mathrm{Kg}$ and $0.14 \mathrm{~g} / \mathrm{Kg}, p<0.05)$ when compared to the negative controls (saline). Despite the observation of inhibited cell migration in both experiments, the number of migratory cells did not differ significantly between the groups.

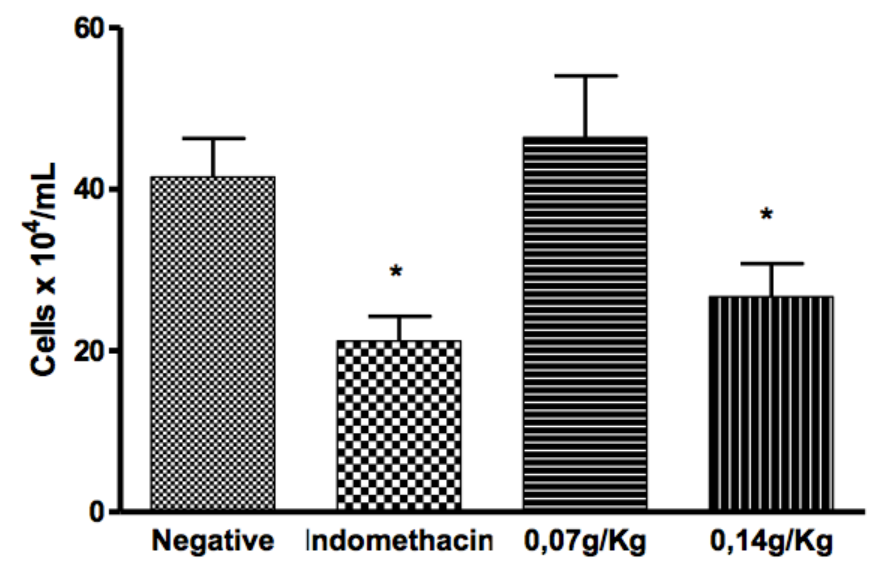

FIGURE 1 - Inhibition of inflammatory cell migration in the peritoneum of Swiss mice inoculated with alcoholic green tea (Camellia sinensis) extract by gavage. Data submitted to variance analysis followed by the Student-Newman-Keuls test.

$*=p<0.05$ in relation to negative control.

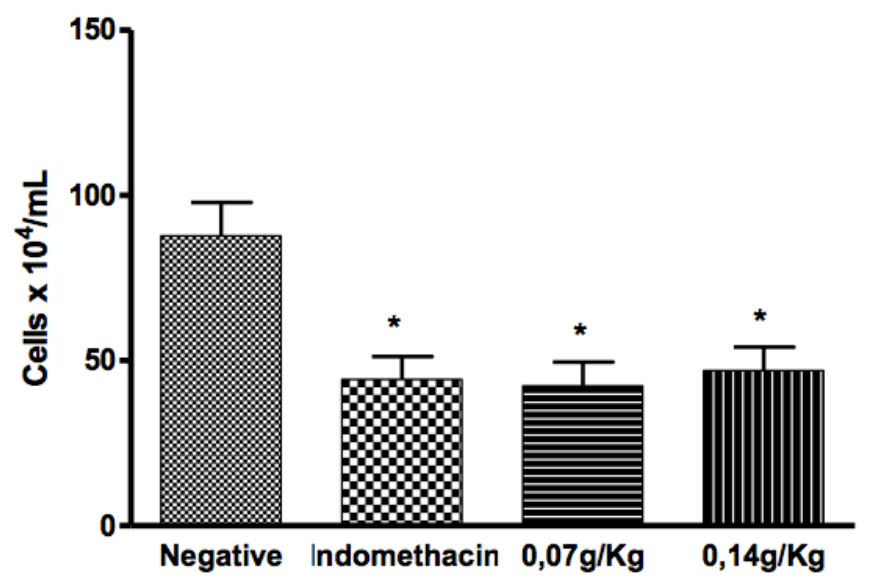

FIGURE 2 - Inhibition of inflammatory cell migration in the peritoneum of Swiss mice inoculated subcutaneously with alcoholic green tea (Camellia sinensis) extract. Data submitted to variance analysis followed by the Student-Newman-Keuls test.

$*=p<0.05$ in relation to negative control.

Figure 3 shows the effect of alcoholic green tea extract and indomethacin on 1\% acetic acid-induced abdominal contortions in Swiss mice. At both dosages $(0.07$ and $0.14 \mathrm{~g} / \mathrm{kg})$, the extract significantly inhibited contortions $(p<0.05)$, though not as strongly as indomethacin $(p<0.01)$. 


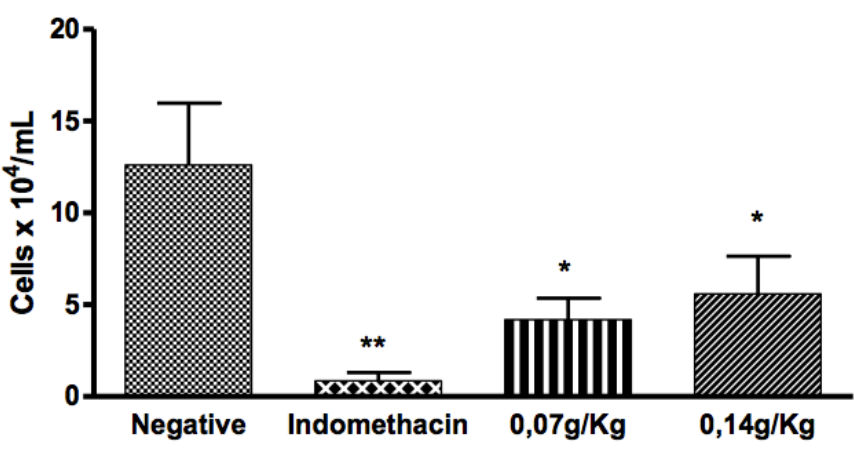

FIGURE 3 - Analgesic effect of alcoholic green tea (Camellia sinensis) extract and indomethacin on Swiss mice with abdominal contortions induced by $1 \%$ acetic acid. Data submitted to variance analysis followed by the Student-Newman-Keuls test.

$* *=p<0.01$ and $*=\mathrm{p}<0.05$ in relation to negative control.

\section{Discussion}

According to several authors, the most important bioactive compounds in green tea are flavonoids and catechin, which act as powerful antioxidants, free radical scavengers, metal chelators, inhibitors of lipoperoxidation and inhibitors of the synthesis of inflammatory pathway components ${ }^{18,19}$. In the present experiment, when administered subcutaneously, alcoholic green tea extracts at both concentrations $(0.07 \mathrm{~g} / \mathrm{Kg}$ and $0.14 \mathrm{~g} / \mathrm{Kg}$ ) inhibited cell migration to the peritoneum of the animals $(p<0.05)$. However, when administered by gavage, only the highest concentration $(0.14 \mathrm{~g} / \mathrm{Kg})$ was efficient $(p<0.05)$, probably because gastrointestinal absorption is less efficient than subcutaneous absorption. The chemical and physical barriers in the stomach (gastric juice and low $\mathrm{pH}$ ) and in the bowels (mucus and proteolytic enzymes) are known to prevent the complete absorption of orally administered substances. In addition, the intestinal microbiota favors the biotransformation of active substances into inactive compounds, reducing the bioavailability of catechin with pharmacological properties ${ }^{20,21}$.

Indomethacin, used in our study as positive control, is a powerful non-hormonal anti-inflammatory substance capable of inhibiting cyclooxygenase and reducing the levels of prostaglandins $\mathrm{A}$ and $\mathrm{E}^{22}$. This anti-inflammatory action was clearly observed in the evaluation of the analgesic effect of indomethacin and alcoholic green tea extracts on Swiss mice with acetic acid-induced abdominal contortions. When administered subcutaneously, the extract reduced contortions significantly $(p<0.05)$ regardless of the concentration $(0.07 \mathrm{~g} / \mathrm{Kg}$ and $0.14 \mathrm{~g} / \mathrm{Kg})$, but indomethacin was more efficient than either concentration $(p<0.01)$, suggesting that in this model, and with this route of administration, the analgesic action of green tea is not dose-dependent.
Found in high concentrations in green tea, epigallocatechin 3-gallate (EGCG) has been the object of much research. It has a selective inhibitory effect on cyclooxygenase 2 (COX-2) and inducible nitric oxide synthase (iNOS) in human chondrocytes. Prostaglandins synthesized from COX-2 reduce the pain threshold during inflammation and help improve cell permeability during cell migration. iNOS synthesizes nitric oxide in endothelial cells, promoting significant vasodilation during inflammation ${ }^{23-25}$. The combined effect of these catechin is likely responsible for the inhibition of cell migration and analgesia observed in the present study, since the inhibition of COX-2 and iNOS is known to reduce vascular permeability and vasodilation, respectively.

However, other mechanisms have been proposed to explain the anti-inflammatory effect of green tea. In a study of the effect of polyphenols from green tea in an experimental rat arthritis model, Kim et al. ${ }^{26}$ found that green tea reduced IL-17 synthesis and increased IL-10 synthesis. IL-17 is synthesized by Th17 lymphocytes during events favoring chronic inflammation. The reduction in IL-17 synthesis can inhibit several processes required for the development of rheumatoid arthritis, such as Th1 lymphocyte activation, macrophage pro-inflammatory cytokine release, and autoantibody synthesis ${ }^{27,28}$.

\section{Conclusion}

Green tea was shown to have analgesic and antiinflammatory properties and may constitute a natural treatment option in chronic inflammatory disorders.

\section{References}

1. Chacko SM, Thambi PT, Kuttan R, Nishigaki I. Beneficial effects of green tea: a literature review. Chin Med. 2010;5:1-9. doi: 10.1186/1749-8546-5-13.

2. Kuriyama S. Green tea consumption and prevention of coronary artery disease. Circulation. 2010;74:248-49. doi: 10.1253/circj.CJ09-1004.

3. Deka A, Vita JA. Tea and cardiovascular disease. Pharmacol Res. 2011;64(2):136-45. doi: 10.1016 / j.phrs.2011.03.009.

4. Senger AEV, Schwanke CHA, Gomes I, Gottlieb MGV. Effect of green tea (Camellia sinensis) consumption on the components of metabolic syndrome in elderly. J Nutr Health Aging. 2012;16(9):73842. doi: 10.1007/s12603-012-0081-5.

5. Suzuki Y, Miyoshi N, Isemura M. Health-promoting effects of green tea. Proc Jpn Acad Ser B Biol Phys Sci. 2012;88(3):88-101. PMID: 22450537.

6. Khan N, Mukhtar H. Multitargeted therapy of cancer by green tea polyphenols. Cancer Lett. 2008;269(2):269-80. doi: 10.1016/j. canlet.2008.04.014.

7. Graham HN. Green tea composition, consumption, and polyphenol chemistry. Prev Med. 1992;21(3):334-50. PMID: 1614995.

8. Balentine DA, Wiseman SA, Bouwens LC. The chemistry of tea 
favonoids. Crit Rev Food Sci Nutr. 1997;37(8):693-704. PMID: 9447270.

9. Matsubara S, Rodrigues-Amaya DB. Teores de catequinas e teaflavinas em chás comercializados no Brasil. Ciênc Tecnol Aliment. 2006;26(2):401-7. doi: 10.1590/S0101-20612006000200024.

10. Recio MC, Andujar I, Rios JL. Anti-inflammatory agents from plants: progress and potential. Curr Med Chem. 2012;19(14):2088103. PMID: 22414101.

11. Kolaczkowska E, Kubes P. Neutrophil recruitment and function in health and inflammation. Nat Rev Immunol. 2013;13(3):159-75. doi: 10.1038/nri3399.

12. Tousoulis D, Kampoli AM, Papageorgiou N, Androulakis E, Antoniades C, Toutouzas K, Stefanadis C. Pathophysiology of atherosclerosis: the role of inflammation. Curr Pharm Des. 2011;17(37):4089-110. PMID: 22204371.

13. Coussens LM, Zitvogel L, Palucka AK. Neutralizing tumorpromoting chronic inflammation: a magic bullet? Science. 2013;339:286-91. doi: 10.1126/science.1232227.

14. Takami S, Imai T, Hasumura M, Cho YM, Onose J, Hirose M. Evaluation of toxicity of green tea catechins with 90-day dietary administration to F344 rats. Food Chem Toxicol. 2008;46(6):22249. doi: 10.1016/j.fct.2008.02.023.

15. Ryu SD, Chung WG. Induction of the procarcinogenactivating CYP1A2 by a herbal dietary supplement in rats and humans. Food Chemical Toxicol. 2003;41:861-6. PMID: 12738191.

16. Islam MA. Cardiovascular effects of green tea catechins: progress and promise. Recent Pat Cardiovasc Drug Discov. 2012;7(2):88-99. PMID: 22670802.

17. Spiller F, Alves MK, Vieira SM, Carvalho TA, Leite CE, Lunardelli A, Poloni JA, Cunha FQ, Oliveira JR. Anti-inflammatory effects of red pepper (Capsicum baccatum) on carrageenan- and antigeninduced inflammation. J Pharm Pharmacol. 2008;60(4):473-8. doi: 10.1211/jpp.60.4.0010.

18. Cabrera C, Artacho R, Gimenez R. Beneficial effects of green tea- a review. J Am Coll Nutr. 2006;25(2):79-99. PMID: 16582024.

19. Speciale UM, Chirafisi J, Saija A, Cimino F. Nutritional antioxidants and adaptive cell responses: an update. Curr Med Mol. 2011;11(9):770-89. PMID: 21999148.

20. Koo MW, Cho CH. Pharmacological effects of green tea on the gastrointestinal system. Eur J Pharmacol. 2004;500(1-3):177-85. PMID: 15464031.

21. Choi YH, Chin YW, Kim YG. Herb-drug interactions: focus on metabolic enzymes and transporters. Arch Pharm Res. 2011;34(11):1843-63. doi: 10.1007/s12272-011-1106-z.

22. Sahin M, Sahin E, Gümüslü S. Cyclooxygenase-2 in cancer and angiogenesis. Exp Vascul Biol. 2009;60(2):242-53. PMID: 15116331.

23. Gullino PM. Prostaglandins and gangliosides of tumor microenvironment: their role in angiogenesis. Acta Oncol. 1995;34(3):439-41. PMID: 7540024.

24. Nie D, Lamberti M, Zacharek A, Li L, Szekeres K, Tang K, Chen Y, Honn KV. Thromboxane A(2) regulation of endothelial cell migration, angiogenesis, and tumor metastasis. Biochem Biophys Res Commun. 2000;267(1):245-51. PMID: 10623605.

25. Ruan YC, Zhou W, Chan HC. Regulation of smooth muscle contraction by the epithelium: role of prostaglandins. Physiology. 2011;26(3):156-70. doi: 10.1152/physiol.00036.2010.
26. Kim HR, Rajaiah R, Wu QL, Satpute SR, Tan MT, Simon JE, Berman $\mathrm{BM}$, Moudgil KD. Green tea protects rats against autoimmune arthritis by modulating disease-related immune events. J Nutr. 2008;138(11):2111-6. doi: 10.3945/jn.108.089912.

27. Pappu R, Ramirez-Carrozzi V, Sambandam A. The interleukin-17 cytokine family: critical players in host defence and inflammatory diseases. Immunology. 2011;134(1):8-16. doi: 10.1111/j.13652567.2011.03465.x.

28. Miossec P, Kolls JK. Targeting IL-17 and TH17 cells in chronic inflammation. Nat Rev Drug Discov. 2012;11(10):763-76. doi: $10.1038 / \operatorname{nrd} 3794$.

\section{Correspondence:}

Silvia Fernandes Ribeiro da Silva

Avenida José Bastos, 3390

60435-160 Fortaleza - CE Brasil

silviafernandes@unifor.br

Received: Dec 18, 2014

Review: Feb 19, 2015

Accepted: Mar 17, 2015

Conflict of interest: none

Financial source: none

${ }^{1}$ Research performed at Laboratory of Immunology, Health Sciences Center, University of Fortaleza (UNIFOR), Fortaleza-CE, Brazil. 